\title{
Tree mortality in a riparian forest at Rio Paraguai, Pantanal, Brazil, after an extreme flooding
}

\author{
Geraldo Alves Damasceno-Junior ${ }^{1,3}$, João Semir², Flavio Antonio Maës dos Santos² and \\ Hermógenes de Freitas Leitão-Filho (in memorian)
}

Received: January 07, 2004. Accepted: May 05, 2004

\begin{abstract}
RESUMO - (Mortalidade de árvores em uma floresta ripária do rio Paraguai, Pantanal, Brasil, após uma cheia excepcional). Foi realizado um estudo numa mata ripária (rio Paraguai, Brasil) para verificar a mortalidade da vegetação após uma cheia excepcional, em 1995. Indivíduos com diâmetro a altura do peito ? $5 \mathrm{~cm}$ foram marcados em 108 parcelas $(10 \times 10 \mathrm{~m})$ em 1994 e reamostrados em 1996. A taxa de mortalidade total foi de $4,1 \%$. A mortalidade aumentou nas faixas topográficas mais altas, ao nível de comunidade, indicando que lugares onde as inundações são mais raras são mais afetados pelas grandes cheias.
\end{abstract}

Palavras-chave : Corumbá, inundação, perturbação, mata ripária, dique marginal

ABSTRACT - (Tree mortality in a riparian forest at Rio Paraguai, Pantanal, Brazil, after an extreme flooding). A study was conducted in a riparian forest (Rio Paraguai, Brazil) to verify the vegetation mortality after an exceptional flooding in 1995 . Individuals with diameter at breast height? $5 \mathrm{~cm}$ were sampled in $108(10 \times 10 \mathrm{~m})$ plots in 1994 , and re-sampled in 1996 . The total mortality rate was $4.1 \%$ per year. The mortality increased with the increasing of topographic positions, at community level, suggesting that places where the flooding is less frequent are more affected by extreme floods.

Key words: Corumbá, flooding, disturbing, riparian forest, riverbank

\section{Introduction}

Processes of recurrent natural disturbance are a very important component of the environmental setting of many plant communities. Regionally and within a landscape, the kinds of natural disturbance vary as function of the topography, substrate and the vegetation present (White 1979). In tropical environments, the maintenance of the diversity through attenuation of the effects of competitive exclusion is attributed to disturbance caused by tree fall. When the gaps arise in the process, local succession is re-conducted to the beginning (Connell 1978; Hubbell et al. 1999; Sheil \& Burslem 2003).

In floodplains, inundations are an important disturbing factor. Besides the anoxia, it causes stream migration, erosion and deposition, creating new substrates and destroying old ones. The ability of species to colonize different environment, dispersion features, tolerance to inundation and shade tolerance create a gradient that reflects the timing and frequency of floods (Junk 1989; White 1979). According to Naiman \& Décamps (1997), the disturbing power and frequency of inundations are inversely proportional forces. Uncommon and exceptional flooding has more power to impact the riparian zones. According to Junk (1989), flooding tolerance can increase when a given tree becomes an adult. Even so, if the duration of the flooding is increased by an unusual inundation, the additional stress produced by anoxia could lead the less tolerant species to die. Nevertheless, there is little information about the effects of exceptional floods on riparian forests (Vervuren et al. 2003.)

The Rio Paraguai is the main river of the Brazilian Pantanal, and is subject to annual flooding. Exceptional floods are rare, with only three registered in the last century, in 1905, 1988 and 1995.

There is no information about patterns of mortality of trees in Pantanal riparian forests at these events. Studies on riparian forests of Rio Paraguai mainly deal

\footnotetext{
1 Departamento de Ciências do Ambiente, Universidade Federal de Mato Grosso do Sul, Campus de Corumbá, Av. Rio Branco 1270, C. Postal 252, CEP 79304-020, Corumbá, MS, Brasil

2 Departamento de Botânica, Instituto de Biologia, Universidade Estadual de Campinas, C. Postal 6109, CEP 13083-970, Campinas, SP, Brazil

3 Corresponding Author: gdamasceno@ terra.com.br
} 
with structure (Dubs 1994; Guarin-Neto et al. 1996; Veloso 1947) or the effects of inundation on the structure and distribution of species (e.g. Adámoli \& Pott 1999; G.A. Damasceno-Junior et al. 1999; Nunes da Cunha \& Junk 1999; Nunes da Cunha \& Junk 2001; Prado et al. 1994).

This study is part of the masters research carried out by the first author between 1994 and 1996. The objectives were to describe the vegetation of riparian forests along the Rio Paraguai, around Corumbá, Mato Grosso do Sul State. During this period, an exceptional flooding occurred in 1995, providing the opportunity to study the mortality in these rare events, so, the aim of this study was to compare the mortality rates of the species in different topographic positions, after the exceptional flooding occurred in 1995, in a riparian forest of the Rio Paraguai. The mortality of individuals occurring in higher positions, where flooding is an unusual event, is expected to be higher than that of individuals occurring in lower positions submitted to annual flooding where the species are theoretically more tolerant to inundation and anoxia.

\section{Material and methods}

Study site - Located on the right riverbank of the Rio Paraguai downstream from the Rabicho ranch between

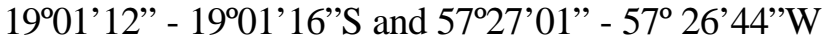
in Pantanal of the Rio Paraguai subregion, municipality of Corumbá, Mato Grosso do Sul State, Brazil (Fig. 1).

The topography of the site is very flat, with a slope that reaches nearly $2 \mathrm{~cm} \cdot \mathrm{km}^{-1}$ in the north-south direction, the same direction that the Rio Paraguai flows. In this area, the river has numerous secondary channels, meanders, oxbow lakes, islands and a large area of seasonally flooded grasslands. The total inundation area of the Rio Paraguai has been varying from nearly 4,000 to $16,000 \mathrm{~km}^{2}$ between low and high water seasons during the last 95yr (Hamilton et al. 1996). The riparian forests are mainly located in convex parts of meanders, where sets of narrow riverbanks are deposited during the floods.

This area, like all of the Pantanal, has a distinct wet and dry season, a dry winter and rainy summer (Awa, according to Köppen system), with a mean annual precipitation of $1,070 \mathrm{~mm}$ (Soriano 1997). At this area, the Rio Paraguai has an unimodal annual system of flooding. The flooding peak is reached in the dry season, with the lowest level occurring in the rainy months (Fig. 2). This occurs because the local inundation depends on the rains of the upper basin,

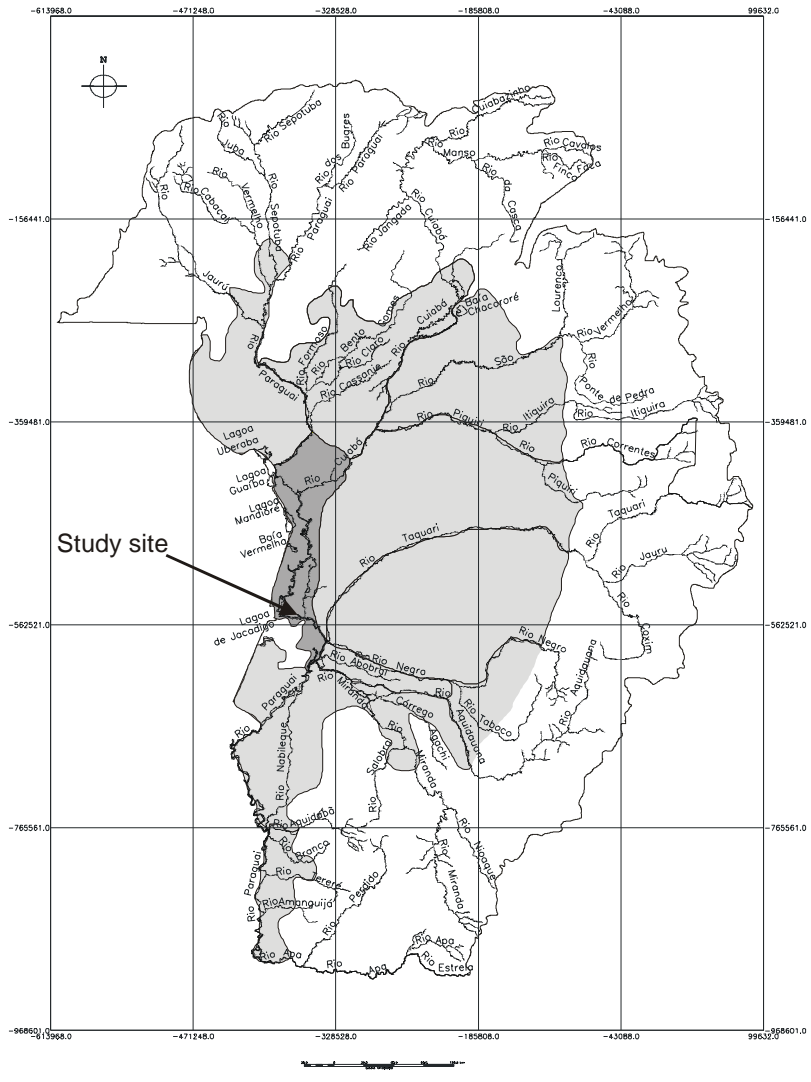

Figure 1. Location of the study area and Alto Paraguai basin, Brazilian Pantanal, according to the Pantanal subdivision made by Adamoli (1982) and modified by Silva \& Abdon (1998). The darkest area is the Pantanal of the Paraguai sub-region.

whose peak flows take about three months to reach the study area. During normal flood periods, only higher riverbanks escape inundation, and in extreme floods, the entire floodplain is inundated.

In the Rio Paraguai floodplain, besides riparian forests, seasonally flooded grasslands and aquatic vegetation in the lagoons and water channels can be found (Bortolotto et al. 1999). The riparian forest varies from evergreen to alluvial semi-deciduous forest, where some deciduous species have a greater number of individuals.

Data collection - A grid of 108 contiguous $10 \times 10 \mathrm{~m}$ plots was systematically established to sample all locations of the riverbank. Because of the variation in the local micro topography, this grid covered all topographic locations of the chosen riverbank. All individuals with at least one branch of $5 \mathrm{~cm}$ or more of DBH (diameter at $1.3 \mathrm{~m}$ above the ground level) were sampled. The trees and shrubs were permanently labelled with a numbered aluminium tag. A voucher specimen of the different species was collected, dried and deposited in 


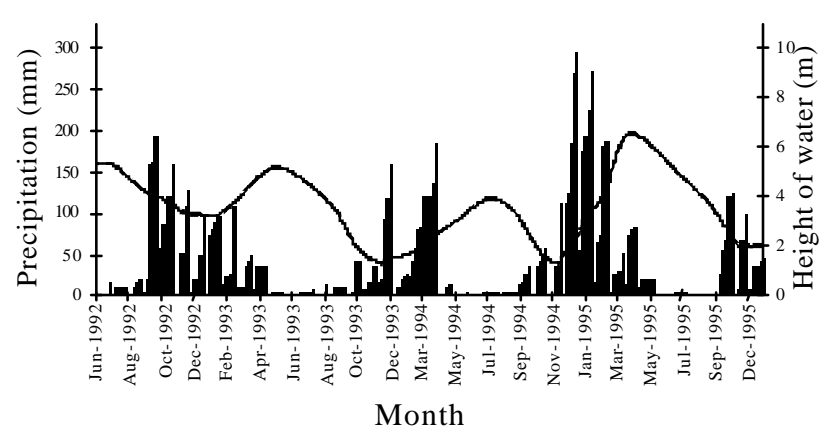

Figure 2. Daily levels of the Rio Paraguai on the Ladário gauge (line) and monthly-accumulated precipitation (bars) in Corumbá between June/1992 and December/1995. Data provided by the Brazilian Navy and Air Force, respectively.

the Herbarium of the Universidade Federal de Mato Grosso do Sul (COR), with duplicates to the Universidade Estadual de Campinas (UEC) and Embrapa (CPAP).

The highest water mark, left by the 1995 flooding on the trunk of each tree, was measured. A staff gauge in the study site recorded the inundation level variation during three months. This variation was the same as shown by the Ladário gauge used by the Brazilian navy which has been collecting daily data since 1900 $\left(\mathrm{R}^{2}=99.85 \%, P<0.001\right)$. Because of this, and to facilitate the historical analysis of flooding on each individual, the measurements of water mark height were transformed into topographic localization of each tree in reference to the zero level of the Ladário gauge. Since the object of this analysis was to investigate the mortality in the different topographic positions, and the original plots were often quite heterogeneous with respect to flooding level, these plots were disregarded. To perform the analysis, the sampling units used were bands defined by their height above the zero level of the Ladário gauge. Each $40 \mathrm{~cm}$ height interval above the zero mark was considered to be a unit.

The period between 1974 and 1996 was considered for an analysis of how much time each topographic position of the surveyed riverbank remained flooded. This was chosen because, after 1974, the inundation regimen of the Rio Paraguai experienced a change, and is now in a period of more regular flooding after a long drought in the 1960's (Fig. 3).

All individuals were measured in 1994, and re-sampled in 1996. To verify if a given individual had died, part of its bark was removed to check if there was humidity in the tissues inside. This was performed for fallen as well as standing trees.

Annual mortality rate was calculated using the model described in Sheil et. al. (1995) and Sheil \& May (1996), where: $m=1-\left(\mathrm{N}_{\mathrm{t}} / \mathrm{N}_{0}\right)^{1 / \mathrm{t}}\left(\mathrm{N}_{0}\right.$ is the number of trees at the first measurement and $\mathrm{N}_{\mathrm{t}}$ is the number of survival trees at the second measurement, and $t$ is the time between the measurements, $2 \mathrm{yr}$ in this study) for each species and $m_{a l l}$ ? 1 ? \{? $\left.\left\{n_{i 0}\left(1 ? m_{i}\right)\right] / ? n_{i 0}\right\}$ is for all species (were $\eta_{0}$ is the initial number of individuals and $m_{1}$ is the mortality rate of the $i^{\text {th }}$ species). Both results were multiplied by 100 and presented in mean percentage per yr.

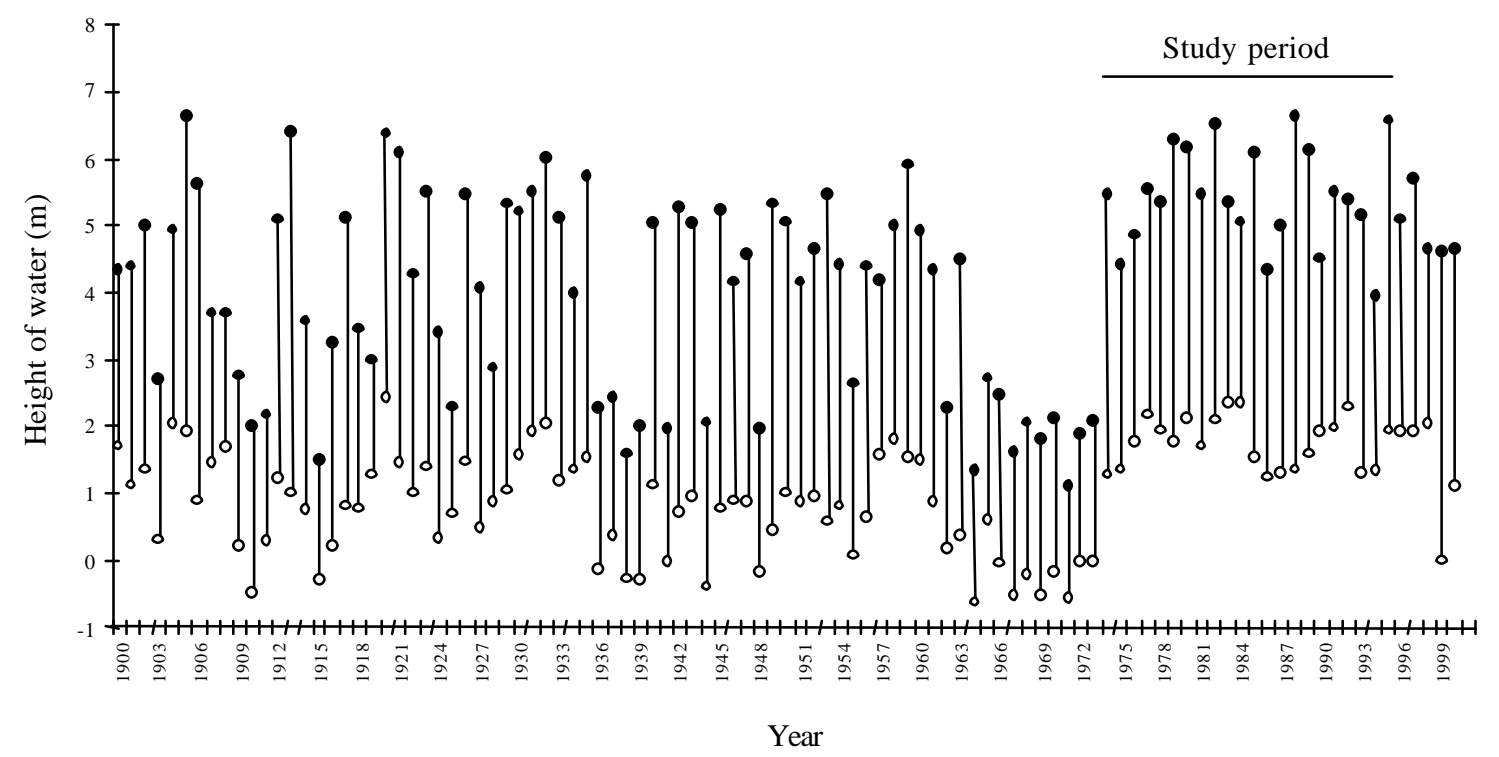

Figure 3. Annual maximum (full circle) and minimum (empty circle) levels of the Rio Paraguai on the Ladario gauge during the entire $20^{\text {th }}$ century, showing the period chosen for this survey, Mato Grosso do Sul, Brazil. Zero is at $83 \mathrm{~m}$ above sea level. Data from the Brazilian Navy. 
To verify the differences between the numbers of dead individuals in the different diameter classes for each species, a chi-squared test was applied. The proportion of dead individuals in the lower diameter class was compared with the proportion of dead individuals in the higher class. For these comparisons, only the initial measures were considered; no recruitment analysis was performed. A regression analysis was applied to verify if the mortality increased with increasing topographic bands (Zar 1996). In this analysis, the mortality index was calculated for all individuals in each topographic band considered.

\section{Results}

The areas up to $3.8 \mathrm{~m}$ high in the riverbank were inundated in all $23 \mathrm{yr}$ considered, being flooded from 120 to 250 days per yr (Fig. 4). The areas between 4.2 and $4.6 \mathrm{~m}$ high were flooded from 19 to $22 \mathrm{yr}$ in the $23 \mathrm{yr}$ analyzed, being from 10 to 20 consecutive years and remained inundated about 90 to 180 days in flooded years. Areas 5 to $6 \mathrm{~m}$ were occasionally inundated, with at least two consecutive yr without inundation, and a maximum of 9yr with consecutive flooding, remaining 11 to 90 days with water, when inundated.

A total of 695 individuals distributed into 37 species were tagged in 1994 (Tab. 1). The mortality rate was $4.11 \%$ per yr, corresponding to 56 dead individuals in $2 \mathrm{yr}$. Among the individuals with $5-15 \mathrm{~cm}$ DBH stems, the mortality was $4.6 \%$ per yr, and among the stems over $15 \mathrm{~cm} \mathrm{DBH}$, it was $3.3 \%$ per yr (Tab. 2).

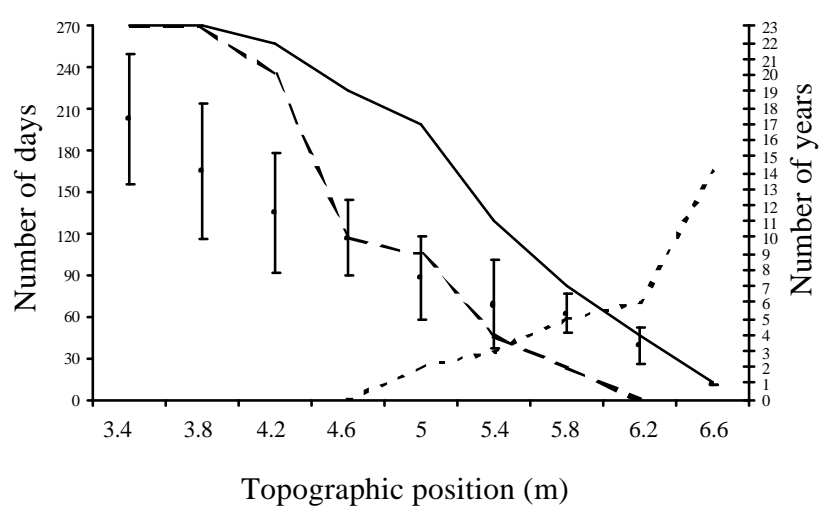

Figure 4. Topographic positions in the riparian forest of Rio Paraguai, Corumbá, Mato Grosso do Sul State, Brazil, between 1974 and 1996 showing: $(-)$ total number of years inundated; (- - ) number maximum of consecutive years inundated; ( I) mean and standard deviaton of days $\mathrm{y}^{-1}$ flooded (only for flooded years); (---) maximum number of consecutive years without flooding.
Table 1. Species sampled in the riparian forest of the Rio Paraguai in Corumbá, Mato Grosso do Sul State, Brazil, with respective botanical families, growth habits and number of individuals $(\mathrm{N})$.

\begin{tabular}{|c|c|c|}
\hline Family/Scientific name & Habitat & $\mathrm{N}$ \\
\hline \multicolumn{3}{|l|}{ ARECACEAE } \\
\hline Acrocomia aculeata (Jacq.) Lodd. & Palm & 3 \\
\hline Bactris glaucescens Drude & Palm & 6 \\
\hline \multicolumn{3}{|l|}{ BIGNONIACEAE } \\
\hline Tabebuia heptaphylla (Vell.) Tol. & Tree & 7 \\
\hline \multicolumn{3}{|l|}{ CAPPARACEAE } \\
\hline Crataeva tapia $\mathrm{L}$. & Tree & 50 \\
\hline \multicolumn{3}{|l|}{ CECROPIACEAE } \\
\hline Cecropia pachystachya Tréc & Tree & 31 \\
\hline \multicolumn{3}{|l|}{ CHRYSOBALANACEAE } \\
\hline Couepia uiti (Mart.\& Zucc.) Bth. & Shrub & 7 \\
\hline \multicolumn{3}{|l|}{ EUPHORBIACEAE } \\
\hline Alchornea castaneifolia (Willd.) A. Juss. & Shrub & 12 \\
\hline Alchornea discolor Poepp. & Tree & 10 \\
\hline Sapium obovatum $\mathrm{Kl}$. & Tree & 2 \\
\hline \multicolumn{3}{|l|}{ FLACOURTIACEAE } \\
\hline Casearia aculeata Jacq. & Shrub & 10 \\
\hline \multicolumn{3}{|l|}{ HIPPOCRATEACEAE } \\
\hline Salacia elliptica (Mart.) Peyr. & Shrub & 1 \\
\hline \multicolumn{3}{|l|}{ LAURACEAE } \\
\hline Ocotea diospyrifolia (Meisn.) Mez & Tree & 56 \\
\hline \multicolumn{3}{|l|}{ LEGUMINOSAE - CAESALPINIOIDEAE } \\
\hline $\begin{array}{l}\text { Hymenaea courbaril L. var. Stilbocarpa } \\
\text { (Hayne) Y.T. Lee \& Langenh. }\end{array}$ & Tree & 1 \\
\hline \multicolumn{3}{|l|}{ LEGUMINOSAE - MIMOSOIDEAE } \\
\hline $\begin{array}{l}\text { Albizia inundata (Mart.) Barneby } \\
\text { \& J.W. Grimes }\end{array}$ & Tree & 19 \\
\hline $\begin{array}{l}\text { Inga vera Willd. ssp. affinis (DC.) } \\
\text { Pennington }\end{array}$ & Tree & 226 \\
\hline Zygia inaequalis (H.B.K.) Pitt. & Shrub & 5 \\
\hline \multicolumn{3}{|l|}{ LEGUMINOSAE - PAPILIONOIDEAE } \\
\hline Andira inermis H.B.K. & Tree & 7 \\
\hline Bergeronia sericea Mich. & Shrub & 2 \\
\hline Pterocarpus micheli Brit. & Tree & 10 \\
\hline \multicolumn{3}{|l|}{ MELIACEAE } \\
\hline Trichilia stellato-tomentosa Kze. & Shrub & 4 \\
\hline \multicolumn{3}{|l|}{ MELASTOMATACEAE } \\
\hline Mouriri guianensis Aubl. & Shrub & 2 \\
\hline \multicolumn{3}{|l|}{ MORACEAE } \\
\hline Brosimum gaudichaudii Tréc. & Shrub & 1 \\
\hline \multicolumn{3}{|l|}{ MYRTACEAE } \\
\hline Eugenia egensis DC. & Shrub & 8 \\
\hline Eugenia cf. polystachya Rich. & Tree & 21 \\
\hline Myrcia cf. mollis (H.B.K.) DC. & Shrub & 21 \\
\hline \multicolumn{3}{|l|}{ NYCTAGINACEAE } \\
\hline Neea hermaphrodita S. Moore & Shrub & 13 \\
\hline \multicolumn{3}{|l|}{ POLYGONACEAE } \\
\hline Coccoloba cf. alagoensis Wedd. & Tree & 12 \\
\hline Ruprechtia brachysepala Meisn. & Tree & 9 \\
\hline Triplaris gardneriana Wedd. & Tree & 70 \\
\hline \multicolumn{3}{|l|}{ RUBIACEAE } \\
\hline Genipa americana $\mathrm{L}$. & Tree & 1 \\
\hline Tocoyena formosa $\mathrm{C} . \& \mathrm{~S}$. & Shrub & 4 \\
\hline
\end{tabular}


Table 1 (continuation)

\begin{tabular}{llc}
\hline Family/Scientific name & Habitat & $\mathrm{N}$ \\
\hline $\begin{array}{lll}\text { SAPINDACEAE } \\
\quad \text { Cupania castaneaeifolia Mart. }\end{array}$ & Tree & 1 \\
$\begin{array}{l}\text { SAPOTACEAE } \\
\quad \text { Pouteria glomerata } \text { (Miq.) Radlk. }\end{array}$ & Tree & 10 \\
$\begin{array}{l}\text { STERCULIACEAE } \\
\quad \text { Guazuma ulmifolia } \text { Lam. }\end{array}$ & Tree & 7 \\
$\begin{array}{l}\text { ULMACEAE } \\
\quad \text { Celtis pubescens } \text { (H.B.K.) Spreng. }\end{array}$ & Shrub & 8 \\
$\begin{array}{l}\text { VERBENACEAE } \\
\text { Vitex cymosa } \text { Bert. }\end{array}$ & Tree & 7 \\
$\begin{array}{l}\text { VOCHYSIACEAE } \\
\text { Vochysia divergens } \text { Pohl }\end{array}$ & Tree & 31 \\
\hline
\end{tabular}

The mortality rates in each topographic region increased from low to high positions, indicating that after the 1995 extreme flood, the trees that were at higher topographic positions had a proportionally greater number of dead individuals (Fig. 5). None of the species with four or more dead individuals showed differences in mortality at different topographic position. Nevertheless, except for Pterocarpus michelli and Eugenia egensis, the other species with one dead individual were found predominantly in high bands where there were at least two consecutives years without flooding in the $23 \mathrm{yr}$ analysed (Tab. 3). That is why the general mortality was proportionally greater in the higher sites. No mortality was recorded for individuals occupying the sites below $3.8 \mathrm{~m}$ (Fig. 5).

Among the species with more than 20 individuals, the mortality rate varied from no mortality in Crataeva tapia, to $32.8 \%$ per yr in Cecropia pachystachya. For Inga vera ssp. affinis, the most abundant species, mortality was $3.15 \%$ per yr. Triplaris gardneriana, Ocotea diospyrifolia and Vochysia divergens showed mortality rates similar to Inga vera. There were no

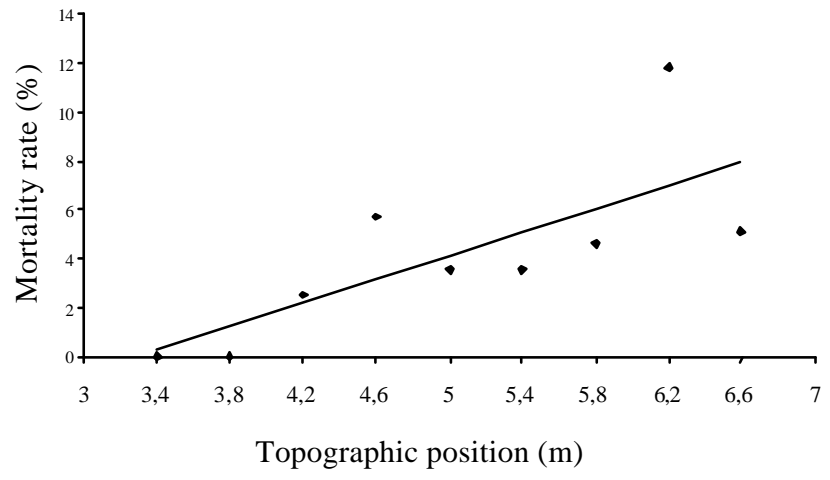

Figure 5. Mortality rate per year at each topographic position in a riparian forest of the Rio Paraguai, Corumbá, Mato Grosso do Sul State, Brazil, between the years 1994 and 1996. The points are the rates obtained and the straight line are from regression analysis $(\mathrm{R}-\mathrm{Sq}=55.8 \%$ and $P=0.02)$. The total number of individuals at each band was $11,7,100,134,158,157,100,18$ and 10 , respectively.

Table 2. Mortality of species in the riparian forest of the Rio Paraguai, Corumbá, Mato Grosso do Sul State, Brazil, between 1994 and 1996. T - total number of individuals; T 5-15 and T >15 - total of individuals with DBH between 5 and $15 \mathrm{~cm}$, and greater than $15 \mathrm{~cm}$; $\mathrm{M}$ - number of dead individuals after two years; $\mathrm{M}$ 5-15 and $\mathrm{M}>15$ - number of dead individuals with DBH between 5 and $15 \mathrm{~cm}$, and greater than $15 \mathrm{~cm} ; \mathrm{m}\left(\% \mathrm{y}^{-1}\right)$ total mortality rate; $\mathrm{m} 5-15\left(\% \mathrm{y}^{-1}\right)$ - mortality rate among the individuals with DBH between 5 and $15 \mathrm{~cm}$; $\mathrm{m}>15\left(\% \mathrm{y}^{-1}\right)$ - mortality rate among individuals with DBH greater than $15 \mathrm{~cm}$. Only the species which had dead individuals are presented in detailed way.

\begin{tabular}{lrrrrrrrrr}
\hline Species & $\mathrm{T}$ & $\mathrm{M}$ & $\mathrm{T} 5-15$ & $\mathrm{M} 5-15$ & $\mathrm{~T}>15$ & $\mathrm{M}>15$ & $\mathrm{~m}\left(\% \mathrm{y}^{-1}\right)$ & $\mathrm{m}^{\left(\% \mathrm{y}^{-1}\right)} 5-15$ & $\mathrm{~m}\left(\% \mathrm{y}^{-1}\right)>15$ \\
\hline Inga vera ssp. affinis & 226 & 14 & 55 & 6 & 171 & 8 & 3.15 & 5.61 & 2.37 \\
Triplaris gardneriana & 70 & 4 & 60 & 3 & 10 & 1 & 2.90 & 2.53 & 5.13 \\
Ocotea diospyrifolia & 56 & 4 & 42 & 3 & 14 & 1 & 3.64 & 3.64 & 3.64 \\
Cecropia pachystachya & 31 & 17 & 20 & 11 & 11 & 6 & 32.80 & 32.92 & 32.58 \\
Vochysia divergens & 31 & 2 & 18 & 1 & 13 & 1 & 3.28 & 2.82 & 3.92 \\
Eugenia cf. polystachya & 21 & 9 & 21 & 9 & 0 & 0 & 24.41 & 24.41 & - \\
Neea hermaphrodita & 13 & 1 & 13 & 1 & 0 & 0 & 3.92 & 3.92 & - \\
Pterocarpus michelli & 10 & 1 & 8 & 1 & 2 & 0 & 5.13 & 6.46 & 0.00 \\
Celtis pubescens & 8 & 1 & 8 & 1 & 0 & 0 & 6.46 & 6.46 & - \\
Eugenia egensis & 8 & 1 & 8 & 1 & 0 & 0 & 6.46 & 6.46 & - \\
Trichilia stelato-tomentosa & 4 & 1 & 4 & 1 & 0 & 0 & 13.40 & 13.40 & - \\
Sapium obovatum & 2 & 1 & 2 & 1 & 0 & 0 & 29.29 & 29.29 & 0.00 \\
Other species & 215 & 0 & 174 & 0 & 41 & 0 & 0.00 & 0.00 \\
Total & 695 & 56 & 433 & 39 & 262 & 17 & 4.11 & 4.61 & 3.30 \\
\hline
\end{tabular}


Table 3. Mortality rates $\left(\% \mathrm{y}^{-1}\right)$ for all species with dead individuals in each topographic position considered in a riparian forest of the Rio Paraguai Corumbá, Mato Grosso do Sul State, Brazil, between 1994 and 1996. Species indicated with “-” didn’t occur in the band.

\begin{tabular}{|c|c|c|c|c|c|c|c|c|c|}
\hline \multirow[t]{2}{*}{ Species } & \multicolumn{9}{|c|}{ Topographic position (m) } \\
\hline & 3.4 & 3.8 & 4.2 & 4.6 & 5 & 5.4 & 5.8 & 6.2 & 6.6 \\
\hline Inga vera ssp. affinis & 0.0 & 0.0 & 4.7 & 0.0 & 4.0 & 2.7 & 3.9 & 0.0 & 13.4 \\
\hline Triplaris gardneriana & 0.0 & - & 1.9 & 4.4 & 3.9 & 0.0 & 0.0 & - & - \\
\hline Ocotea diospyrifolia & 0.0 & - & 10.6 & 8.7 & 0.0 & 0.0 & 0.0 & 0.0 & - \\
\hline Eugena cf. polystachya & - & - & 10.6 & 34.5 & 22.5 & 29.3 & 29.3 & - & - \\
\hline Eugenia egensis & - & - & 100.0 & - & 0.0 & 0.0 & 0.0 & - & - \\
\hline Pterocarpus micheli & - & - & 0.0 & 0.0 & 0.0 & 100.0 & 0.0 & - & - \\
\hline Cecropia pachystachya & - & - & - & 46.5 & 13.4 & 33.3 & 34.5 & 29.3 & - \\
\hline Neea hermaphrodita & - & - & - & 0.0 & 0.0 & - & 8.7 & - & - \\
\hline Vochysia divergens & - & - & - & 0.0 & 10.6 & 0.0 & 10.6 & 0.0 & - \\
\hline Sapium obovatum & - & - & - & 100.0 & - & 0.0 & - & - & - \\
\hline Celtis pubescens & - & - & - & - & - & - & 0.0 & 18.4 & 0.0 \\
\hline Trichilia stelato-tomentosa & - & - & - & - & - & - & 0.0 & 29.3 & - \\
\hline
\end{tabular}

differences in mortality when trees with $5-15 \mathrm{~cm} \mathrm{DBH}$ stems were compared with those with $\mathrm{DBH}$ greater than $15 \mathrm{~cm}$ for any species (chi-square test $\mathrm{p}>0.08$ Tab. 2). In other words, the flooding affected the trees equally regardless of their age.

Cecropia pachystachya showed the highest annual mortality in the years studied. Eugenia cf. polystachya showed the second highest mortality rate among the species with 20 or more individuals $(24.4 \%$ per yr). All the individuals of Eugenia cf. polystachya, which is an understorey species, measured less than $15 \mathrm{~cm} \mathrm{DBH}$. The remaining species reported in Tab. 1 with low number of total individuals or of dead individuals were cited only for calculation of the total mortality index at the community level.

\section{Discussion}

There are few studies dealing with mortality in tropical environments, especially in riparian zones. Mortality rates for tropical trees cited in the literature reach around $2 \%$ per yr, being higher under stress caused by natural (like El Niño) and human impacts, reaching 6 to $7 \%$ per yr or even $9 \%$ per yr in edges of fragmented tropical forests (Aiba \& Kitayama 2002; Burslem et al. 2000; Laurance et al.1998; 2001; Mesquita et al. 1999). Using the mortality index of Swaine (1987), which has little difference in terms of absolute results from the one used here, Felfili (1995) found $3.5 \%$ in 6yr of observation in a gallery forest in central Brazil; in three seasonally flooded forests with different ages, Campbell et al. (1992) found 1.99\%, $1.56 \%$ and $1.7 \%$ during a normal year of observation.
The annual mortality rate obtained for trees in the Rio Paraguai was high ( $4.11 \%$ per yr) compared with other tropical areas, as cited above.

The real annual mortality in the year 1995 could have in fact been higher than presented here. This is because the index obtained is from a mean of two years (1994 and 1995), aggregating the mortality in 1994 with the mortality in 1995, when the exceptional flood occurred. In spite of being a mean from two years, this high rate may be associated with the exceptional flooding level reached by the Rio Paraguai in 1995, which was the second highest since 1974 . Flooding is a regular event in the study area, and hence, theoretically, its effects are absorbed by the community. Nevertheless, in exceptionally high floods, some phenomena work in a different way than in lower ones. The water speed is faster; the sedimentation rate could be high, reaching up to $10 \mathrm{~cm}$ of sand in some points (Damasceno-Junior pers. obs.); edge points of the riverbank lose some of their soils, and many trees can fall as a consequence; and the time during which the highest topographic parts remain inundated is longer. Certainly, these aspects contributed to the high mean mortality obtained, especially on the high parts, where the effects of stream velocity and water permanence were larger.

Differences between mortality in low and high classes of DBH have been found in situations of stress caused by dry period (Aiba \& Kitayama 2002; Condit et al. 1995) and with different histories of past disturbance or edge effect (Oliveira-Filho et. al. 1997). For the exceptional flooding studied, there is no tendency for high mortality occurs among young 
individuals. This is probably because the event affects the entire populations of trees with the same intensity.

The mortality was high; especially for Cecropia pachystachya and Eugenia cf. polystachya. In C. pachystachya, the values may be easily associated with the exceptional flooding in 1995. C. pachystachya is a pioneer species with a weak trunk structure. Although the causa mortis was not recorded, many individuals of this species fell during the inundation due to the water current. Condit et al. (1995) found high mortality for Cecropia obtusifolia during an unfavourable dry period, and Felfili (1995) found the highest value of mortality for pioneer species in a gallery forest. For Eugenia cf. polystachya, the high mortality can be the result of its understorey location, which is vulnerable to falling branches or whole trees, the fast water current, and the floating mats carried by the water. In tropical rain forests, understorey species also had high mortality rates (Condit et al. 1995; Swaine et al. 1987).

Species like Triplaris gardneriana, Vochysia divergens and Ocotea diospyrifolia did not seem to have been affected by the exceptional high flood. Triplaris gadneriana occurs predominantly in low places and the other two are indifferent to topographical position (Damasceno-Junior pers. obs.). Besides, there were no dead trees from any species below $3.8 \mathrm{~m}$ sites, that were inundated all the $23 \mathrm{yr}$ considered. Probably they are well adapted to being flooded during most of the months every year (see Fig. 4).

Although for some species like Cecropia pachystachya and Eugenia cf. polystachya, the exceptional flood had more impact, there were no differences between mortality in lower and higher locations for any species. This high flood increased the flooding time and the effects of the speed of the water flow across the whole occurrence band for each species. These phenomena increased mortality throughout the whole topographic band of occurrence in the species affected, and not in the bands artificially defined for this study. Because of this, the tendency to have increasing mortality in the higher topographic positions is only detectable at the community level and not for any isolated species. This is a very subtle effect, in which the effects of the increase in flooding time and speed of water flow become progressively stronger with increasing height of the location.

The higher mortality observed in higher locations may be, in part, due to the possibility that species located at the same height have similar tolerance of flooding. Nevertheless, the events were apparently not sufficiently strong to cause intense reductions in all populations, since in the majority of species from higher locations, a small number of individuals died. This may be to the fact that the individuals studied were adults, which according Junk (1989), would be more resistant to flooding.

In conclusion, expectations regarding increasing mortality in higher topographic locations were confirmed mainly at the community level, but were not detectable at the species level. The exceptional flood affected the system because of its unusual occurrence, especially in the parts of the community where the flood does not reach every year. The flood increases the chances of mortality for more species in higher locations, but not necessarily in great numbers.

Another point is that this flood also modified the configuration of the landscape. Vervuren et al. (2003) suggest that extreme floods can determine the distribution of species for many years on the Rhine River. In this study the data do not permit take conclusions about this subject, but it should be investigated in future studies to complement the data presented here. This will point to new directions to the study of the role played by inundations on the dynamics of seasonally flooded vegetation in the Pantanal.

\section{Acknowledgements}

We are grateful to the Brasilian Navy for the permission to work on the Rabicho farm; to Drs. Arnildo Pott and Ronald Fortney, for the first revision of this manuscript; to Antonio Glauter Cavalheiro, Denilson A. dos Santos and the students Diogenes P. Rodriguez, Luiz Claudio Baracat, Ligia Teixeira, and Andrea Sanches who helped during the field work; two anonymous reviewers; CAPES (Coordenação de Aperfeiçoamento de Pessoal de Nível Superior) and Universidade Federal de Mato Grosso do Sul who sponsored this work.

\section{References}

Adámoli, J. \& Pott, A. 1999. Estudo fitossociológico e ecológico do Pantanal dos Paiaguás. Pp. 215-225. In: Anais do II simpósio sobre recursos naturais e sócioeconômicos do Pantanal: manejo e conservação . Embrapa Pantanal, Corumbá.

Aiba, S. \& Kitayama, K. 2002. Effects of the 1997-98 El Niño drought on rain forests of Mount Kinabalu, Borneo. Journal of Tropical Ecology 18: 215-230. 
Bortolotto, I.M.; Damasceno-Junior, G.A. \& Isquierdo, S.W.G. 1999. Caracterização das unidades fitofisionômicas da bacia da lagoa Negra - Ladário - MS. Pp. 283-289. In: Anais do II simpósio sobre recursos naturais e sócioeconômicos do Pantanal: manejo e conservação. Embrapa Pantanal, Corumbá.

Burslen, D.F.R.P.; Whitmore, T.C. \& Brown, G.C. 2000. Shortterm effects of cyclone impact, and long term recovery of tropical rain forest on Kolombangara, Solomon Islands. Journal of Ecology 88: 1063-1078.

Campbell, D.G.; Stone, J.L. \& Rosas-Jr., A. 1992. A comparison of the phytosociology and dynamics of three floodplain (Várzea) forests of known ages, rio Juruá, western Brazilian Amazon. Botanical Journal of the Linnean Society 108: 213-237.

Condit, R.; Hubbel, S.P. \& Foster, R.B. 1995. Mortality rates of 205 neotropical tree and shrub species and the impact of a severe drought. Ecological Monographs 65(4): 419-439.

Connell, J.H. 1978. Diversity in tropical rain forests and coral reefs. Science 199: 1302-1310.

Damasceno-Junior, G.A.; Bezerra, M.A.O.; Bortolotto, I.M. \& Pott, A. 1999. Aspectos florísticos e fitofisionômicos dos capões do Pantanal do Abobral. Pp. 203-214. In: Anais do II Simpósio sobre recursos naturais e sócioeconômicos do Pantanal: manejo e conservação. Embrapa Pantanal, Corumbá.

Dubs, B. 1994. Differentiation of woodland and wet savanna habitats in the Pantanal of Mato Grosso, Brazil. Betrona-Verlag. Küsnacht, Switzerland.

Felfili, J.M. 1995. Growth, recruitment and mortality in the Gama gallery forest in central Brazil over six year period (1985-1991). Journal of Tropical Ecology 11: 67-83.

Guarin-Neto, G., Guarim, V.L.M.S., Moraes, E.C.C. \& Ferreira, L.A.D. 1996. Fitossociologia de matas ciliares no Pantanal Mato-Grossense. Boletim do Museu Paraense Emílio Goeldi, série Botânica 12(2): 251-263.

Hamilton, S.K.; Sippel, S.J. \& Melack, J.M. 1996. Inundation patterns in the Pantanal wetland of South America determined from passive microwave remote sensing. Archiv fur Hydrobiologie 137(1): 1-23.

Hubbell, S.P.; Foster, R.B.; O’Brien, S.T.; Harms, K.E.; Condit, R.; Wechsler, B.; Wright, S.J. \& Loo De Lao, S. 1999. Light-gap disturbances, recruitment limitation, and tree diversity in a neotropical forest. Science 283(5401): 554-557.

Junk, W.J. 1989. Flood tolerance and tree distribution in Central Amazonian floodplains. Pp. 47-64. In: L.B. Nielsen; I.C. Nielsen \& H. Balslev (eds.). Tropical forests: Botanical dynamics, speciation and diversity. Academic Press, London.

Laurance, W.F.; Ferreira, L.V.; Rankin-De-Merona, J.M. \& Laurence, S.G. 1998. Rain forest fragmentation and the dynamics of Amazonian tree communities. Ecology 79(6): 2032-2040.

Laurance, W.F.; Williamson, G.B.; Delamonica, P.; Oliveira, A.; Lovejoy, T.E.; Gascon, C. \& Pohl, L. 2001. Effects of a strong drought on Amazonian forest fragments and edges. Journal of Tropical Ecology 17: 771-785.
Mesquita, R.C.G.; Delamonica, P. \& Laurance, W.F. 1999. Effect of surrounding vegetation on edge-related tree mortality in Amazonian Forest fragments. Biological Conservation 91: 129-134.

Naiman, R.J. \& Décamps, H. 1997. The ecology of the interfaces: riparian zones. Annual Review of Ecology and Systematics 28: 621-658.

Nunes-Da-Cunha, C. \& Junk, W.J. 1999. Composição florística de capões e cordilheiras: Localização das espécies quanto ao gradiente de inundação no Pantanal de Poconé, MT, Brasil. Pp. 387-405. In: Anais do II Simpósio sobre recursos naturais e sócio-econômicos do Pantanal: manejo e conservação. Embrapa Pantanal, Corumbá.

Nunes-Da-Cunha, C. \& Junk, W.J. 2001. Distribution of woody plant Communities along the flood gradient in the Pantanal of Poconé, Mato Grosso, Brazil. International Journal of Ecology and Environmental Sciences 27: 63-70.

Oliveira-Filho, A.T. 1997. Effects of past disturbance and edges on tree community structure and dynamics within a fragment of tropical semideciduous forest in southeasten Brazil over a five year period (1987-1992). Plant Ecology 131: 45-66.

Prado, A.L.; Heckman, C. \& Martins, F.R. 1994. The seazonal sucession of biotic communities in wetlands of the tropical wet-and-dry climatic zone: II. The aquatic macrophyte vegetation in the Pantanal of Mato Grosso, Brazil. Internationale Revue der Gesamten Hydrobiologie 79(4): 569-589.

Sheil, D.; Burslen, D.F.R.P. \& Alder, D. 1995. The interpretation and misinterpretation of mortality rate measures. Journal of Ecology 83: 331-333.

Sheil, D. \& Burslen, D.F.R.P. 2003. Disturbing hypotheses in tropical forests. Trends in Ecology and Evolution 18(1): 18-26.

Sheil, D. \& May, R. 1996. Mortality and recruitment rate evaluations in heterogeneous tropical forests. Journal of Ecology 84: 91-100.

Silva, J.S.V. \& Abdon, M.M. 1998. Delimitação do Pantanal Brasileiro e suas sub-regiões. Pesquisa Agropecuaria Brasileira 33: 1703-1701. Número especial.

Soriano, B.M.A. 1997. Caracterização climática de Corumbá, MS. (Boletim de Pesquisa, 11). Embrapa/Cpap, Corumbá.

Swaine, M.D.; Lieberman, D. \& Putz, F.E. 1987. The dynamics of tree populations in tropical forest: a review. Journal of Tropical Ecology 3: 359-366.

Veloso, H.P. 1947. Considerações gerais sobre a vegetação do Estado de Mato Grosso. Memórias do Instituto Oswaldo Cruz 45(1): 253-272.

Vervuren, P.J.A.; Blom, C.W.P.M. \& Kroon, H. De. 2003. Extreme flooding events on the Rhine and the survival and distribution of riparian plant species. Journal of Ecology 91: 135-146.

White, P. 1979. Pattern, process, and natural disturbance in vegetation. The Botanical Review 45: 229-299.

Zar, J.H. 1996. Biostatistical analysis. Prentice Hall, New Jersey. 